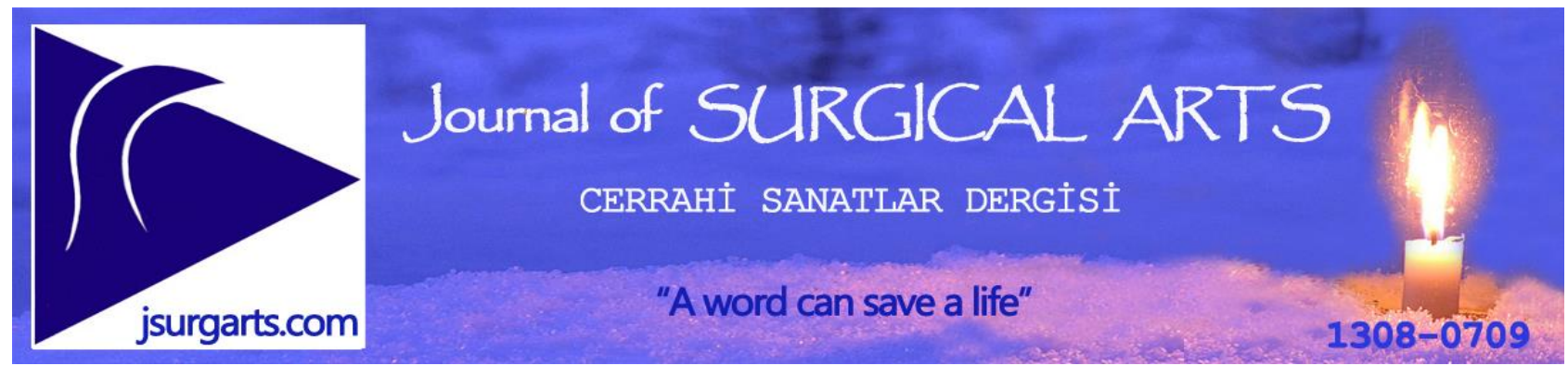

Original study

\title{
External and internal oblique abdominis muscle release (eimr) for complex incisional hernia repair: Modification of partition surgical technique
}

\section{Kompleks insizyonel herni onarımında eksternal ve internal kas serbestlenmesi (EIKS): Partition tekniğinin modifikasyonu}

\author{
Mustafa Özsoy \\ Yıldırım Beyazıt University, Faculty of Medicine, Department of General Surgery ${ }^{1}$, Ankara, Turkey \\ Address: Dr. Mustafa Özsoy, dr.mustafaozsoy@gmail.com \\ How to cite: Özsoy M. External and internal oblique abdominis muscle release (eimr) for complex incisional \\ hernia repair: Modification of partition surgical technique. J Surg Arts 2021;14(2):69-76. \\ DOI: http://dx.doi.org/10.14717/jsurgarts-210204
}

Received: 19.02.2021 Accepted: 05.07.2021

\section{ABSTRACT}

Incisional hernia is the name given to hernias that form in the incision site after abdominal operations. The only treatment option for incisional hernias is surgery and the repair of incisional hernias is still a serious issue for surgeons. The aim of this study is to present an alternative surgical treatment procedure for the treatment of incisional hernias.

The study included patients who were diagnosed with complex incisional hernia and underwent surgery between November 2016 and December 2017. In addition to demographic data such as age and gender, the operative and postoperative morbidity and mortality rates were documented. The patients who underwent additional surgical procedure other than herniography were excluded from the study.

The study included 16 patients who met the inclusion criteria. Of 16 patients, nine $(56.25 \%)$ were male and seven $(43.75 \%)$ were female. The mean age of the patients was 51.25 years and the mean body mass index was $25.3 \mathrm{~kg} / \mathrm{m}^{2}$. The hernia size measured in the computed tomography was $11.01 \mathrm{~cm}$ on average in men and 11.56 $\mathrm{cm}$ on average in women. The intravesical pressure measured intraoperatively before the surgery was $3.4 \mathrm{mmHg}$ on average. While the mean intravesical pressure was found as $12.25 \mathrm{mmHg}$ after the abdomen was closed, the mean intravesical pressure was measured as $6.43 \mathrm{mmHg}$ after the relaxation incision and graft installment. The duration of the surgery was 48 minutes on average. In the postoperative period, paralytic ileus responsive to treatment was observed in two patients and skin necrosis was observed in one patient. No pulmonary embolism, respiratory problems and compartment syndrome that may cause mortality developed in patients. No recurrence was observed in patients in the control one year after the surgery.

The golden standard surgical method for the incisional hernia surgery has yet to be determined. There is still a need for prospective randomized studies. We believe that our technique can be an alternative to other techniques in the incisional hernia surgery due to its easy applicability and low rate of complications.

Keywords: Incisional hernia, abdominal wall repair, component separation, partition technique.

\section{ÖZET}

İnsizyonel herni, karın ameliyatlarından sonra kesi yerinde oluşan hernilere verilen isimdir. Tek tedavi seçeneği cerrahi olan insizyonel hernilerin tamiri halen cerrahlar için ciddi bir sorun teşkil etmektedir. Bu makalemizde insizyonel hernilerin tedavisinde alternatif cerrahi tedavi prosedürümüzü sunmayı amaçladık. 
Çalışmaya Kasım 2016 ile Aralık 2017 yılları arasında kompleks insizyonel herni tanısı ile cerrahi tedavi uygulanmış hastalar dahil edildi. Yaş, cinsiyet gibi demografik verilerinin yanı sıra operatif ve postoperatif morbidite ve mortalite oranları dokümante edildi. Herniografi dışında ek cerrahi prosedür uygulanan hastalar çalışmadan çıkartılmıştır.

Çalışmaya kriterleri taşıyan 16 hasta dahil edilmiştir. 16 hastanın 9'u (\%56,25) erkek iken 7'si $(\% 43,75)$ kadın cinsiyet idi. Hastaların genel yaş ortalaması 51,25 yıl ve vücut kitle indeksi ortalama $25,3 \mathrm{~kg} / \mathrm{m}^{2} \mathrm{olarak}$ saptand. Bilgisayarlı tomografide ölçülen herni çapı erkeklerde ortalama $11,01 \mathrm{~cm}$ iken kadınlarda $11,6 \mathrm{~cm}$ saptandı. Cerrahi öncesi intraoperatif ölçülen mesane içi basıncı ortalama $3.4 \mathrm{mmHg}$ saptandı. Karın kapatıldıktan sonra ortalama mesane içi basınc1 $12.25 \mathrm{mmHg}$ saptanırken relaksasyon insizyonu ve greft konulduktan sonra ortalama mesane içi basınç $6,43 \mathrm{mmHg}$ olarak ölçüldü. İntraoperatif hemoraji ortalama $100 \mathrm{cc}$ ve cerrahi süresi ortalama 48 dakika saptandı. Postoperatif dönemde 2 hastada medikal tedaviye yanıt veren paralitik ileus ve 1 hastada cilt nekrozu saptandi. Hiçbir hastada mortaliteye neden olabilecek pulmoner emboli, respiratuvar problemler ve kompartman sendromu ile karşılaşılmamıştır. Cerrahi sonrası birinci yıl kontrolünde hiçbir hastada nüks saptanmamıştır.

İnsizyonel herni cerrahisinde altın standart cerrahi tedavi yöntemi halen ortaya konulamamıştır. Halen prospektif randomize çalışmalara ihtiyaç duyulmaktadır. Tekniğimizin kolay uygulanabilir olması, düşük komplikasyon oranları ile insizyonel herni cerrahisinde diğer tekniklere alternatif olabileceği düşüncesindeyiz. tekniği

Anahtar kelimeler: İnsizyonel herni, rekonstrüksiyon, component ayrıștırma, katmanlarına ayrıștırma

\section{INTRODUCTION}

Incisional hernia is the name given to hernias that form in the incision site after abdominal operations. The only treatment option for incisional hernias is surgery and the repair of incisional hernias is still a serious issue for surgeons. Various incision types, closing types and sutures have been described to prevent hernias (1). The ratio of incisional hernia reduced to almost $10 \%$ with the use of synthetic prosthesis materials and tension-free reconstruction techniques toward the end of the 1950s (2). Many synthetic and non-synthetic prosthesis materials have been provided to the use of surgeons in today's world. Each has specific advantages and disadvantages. Therefore, an ideal prosthesis material is yet to be determined. In addition to the prosthesis material, the surgical technique is the main topic of discussion (3). The repair of difficult ventral hernias causes serious perioperative morbidity. Additionally, abdominal compartment syndrome, pulmonary embolism and respiratory failure secondary to increased intraabdominal pressure after the repair of large abdominal wall defect may result in mortality (4). This study was conducted to describe our surgical procedure for the treatment of incisional hernias.

\section{MATERIAL and METHOD}

The study included patients who were diagnosed with incisional hernia and underwent surgery in Private Parkhayat Hospital between November 2016 and December 2017. In addition to demographic data such as age and gender, the operative and postoperative morbidity and mortality rates were documented. All patients had a computed tomography scan for additional pathologies to be detected and the size of hernia sac to be measured in the preoperative period (Figure 1). The size of the incisional hernia was calculated by measuring from the widest medial edges of two rectus muscle. Only complex incisional hernias with a size above $10 \mathrm{~cm}$ were included in this study (Figure 2). The patients with a hernia in the size below $10 \mathrm{~cm}$ and those who underwent additional surgical procedure other than herniography were excluded from the study.

\section{Surgical technique}

All surgical procedures were performed under general anesthesia. Before the anesthesia, all patients were installed epidural catheter for postoperative analgesic, anti-embolism stockings for embolism prophylaxis, and under patient warmers were placed under patients. Cephalosporin group antibiotherapy was preferred for prophylactic antibiotherapy. Intravesical pressure measurement catheter was installed to measure the intravesical pressure before the surgery, after closing the fascia defect and at the end of the surgery, and the measurements were documented. The operation starts after cleaning the surgery area. All surgical procedures were performed by the only experienced surgeon.

1-) The midline is incised including the former incision. The scar tissue that is aesthetically bad looking, has weak alimentation and adhered to the hernia sac is included into the incision (Figure 3).

2-) The scar tissue over the hernia sac is excised without opening a percutaneous and adipose tissue sac. Hernia sac is excised from the adjacent tissue with blunt and precise dissection. The dissection is continued until finding the rectus cover (Figure 4).

3-) Skin flap is dissected to the $2 \mathrm{~cm}$ lateral from the junction of the musculus obliquus externus abdominis aponeurosis and rectus cover (Figure 5).

4-) After determining the edges of the rectus abdominis muscle around the hernia sac, hernia sac is closed with continuous suture with loop prolene 
no:0 (Ethicon $40 \mathrm{~mm}^{1} / 2 \mathrm{c} 125 \mathrm{~cm}$ ) from defect cranial towards caudal without opening the sac (Figure 6).

5-) After closing the incisional hernia defect, aponeurosis of obliquus externus and internus abdominis muscle is detached from the lateral edge of the rectus cover so as to see the transverse abdominis muscle. Dissection is avoided to prevent nerve injury as well as epigastric artery and vein injury (Figure 7).

6-) Polypropylene mesh at the size of $30 * 30$ is fixated with continuous suture to the externus and internus aponeurosis line freed in the lateral and 5 $\mathrm{cm}$ away from the incision line in the cranial and

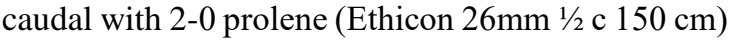
(Figure 8).

7-) Two negative-pressurized aspiration drainages are installed after hemostasis. The skin and percutaneous are closed with absorbable suture.

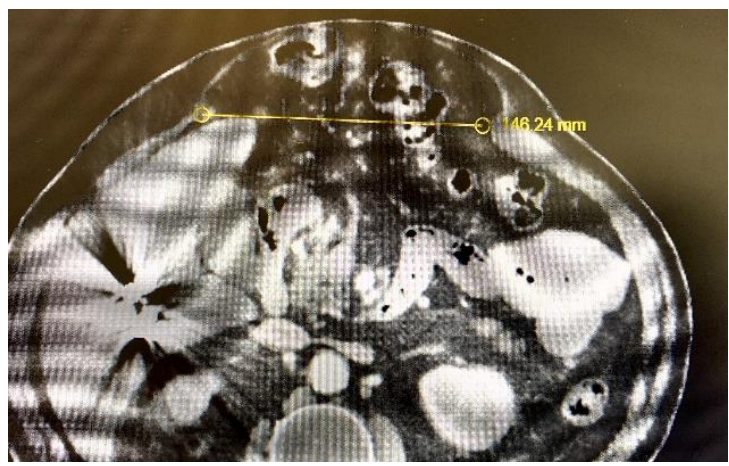

Figure 1: Computed tomography was obtained to measure the hernia sac in the preoperative period.

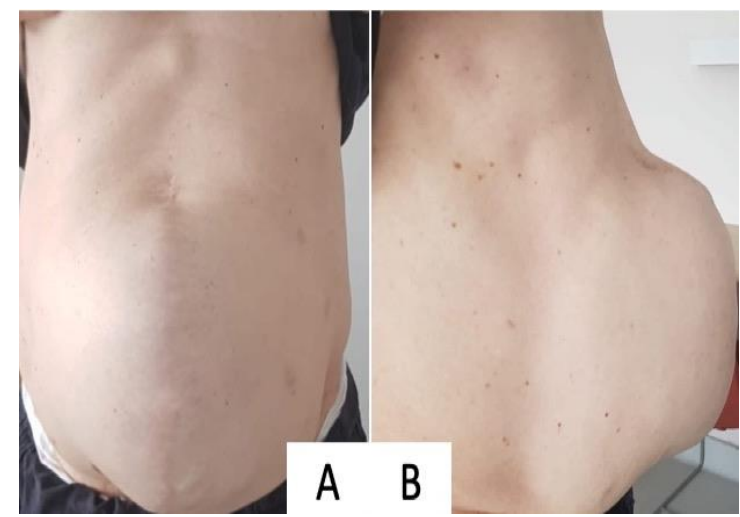

Figure 2: The previous surgical incision of all patients included in the study was median superior and inferior.

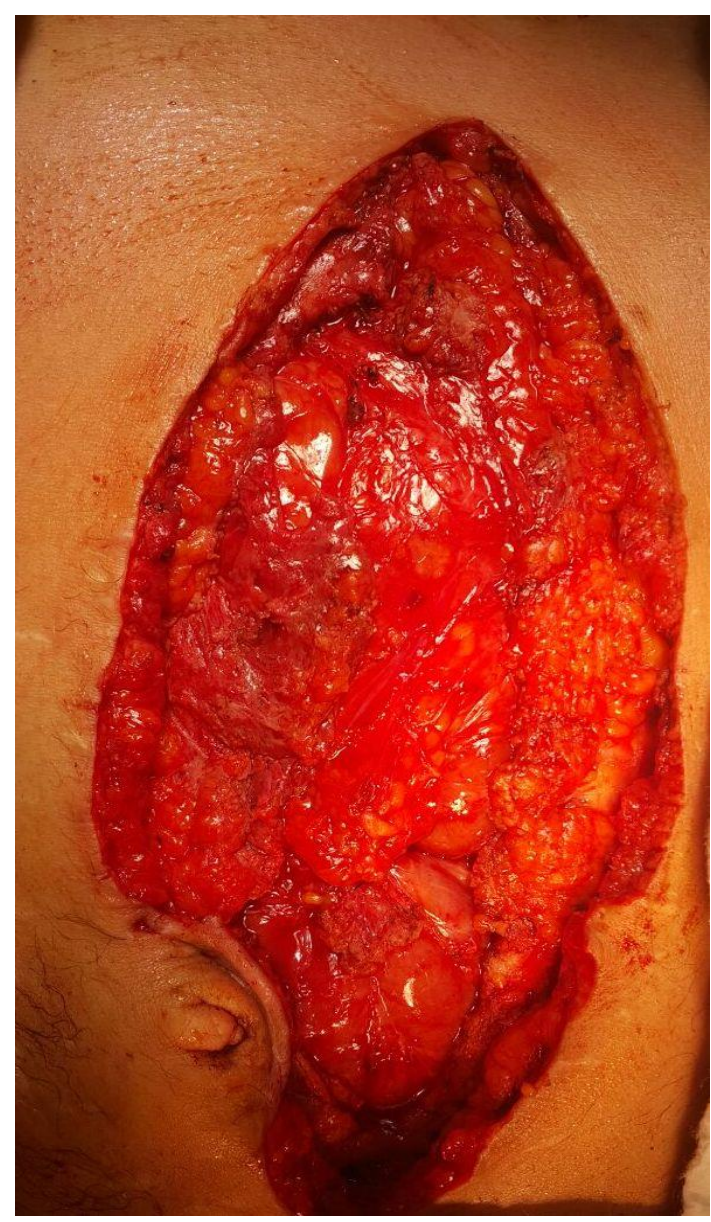

Figure 3: Aesthetically poor scar tissue is excised

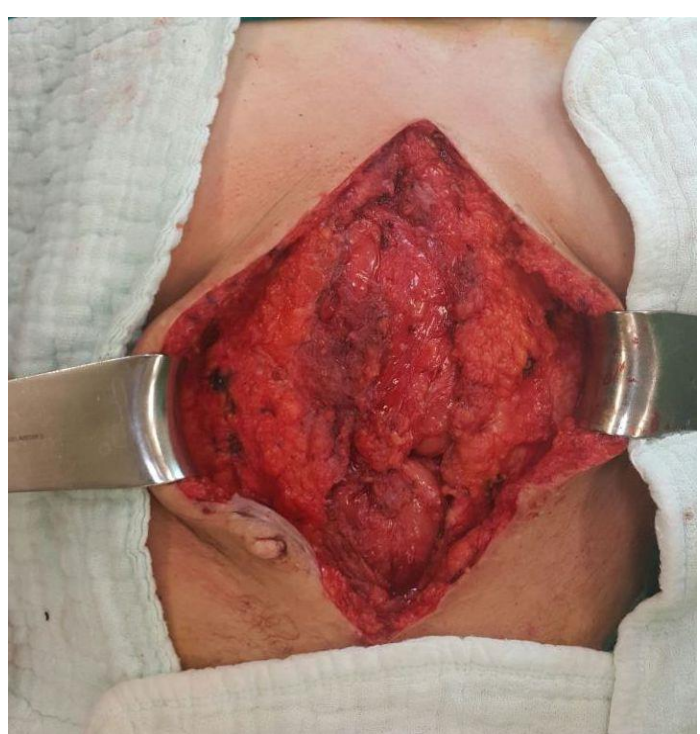

Figure 4: Without opening the hernia sac, it is separated from the surrounding tissue by a blunt and precise dissection. Dissection is continued until the rectus sheath is found. 


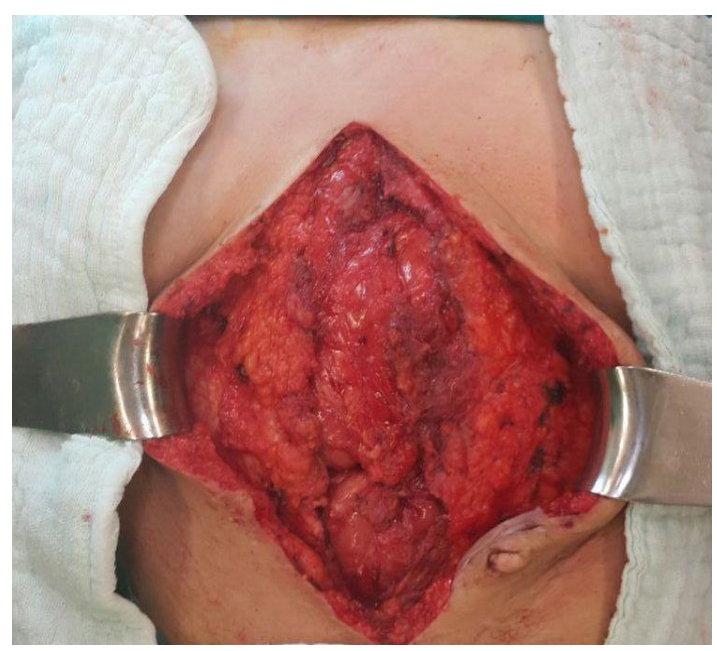

Figure 5: The skin flap is dissected up to $2 \mathrm{~cm}$ lateral from the junction of musculus obliquus externus abdominis aponeurosis with the rectus sheath.

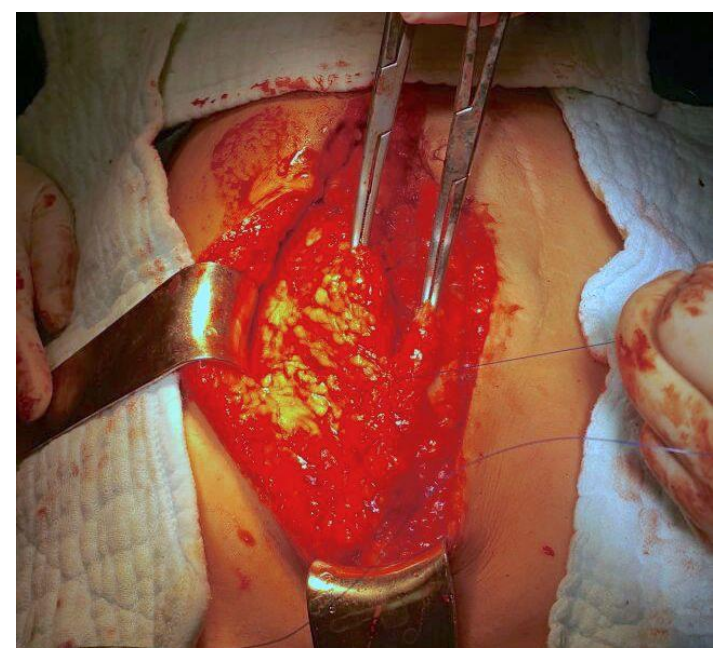

Figure 6: Without opening the hernia sac, the defect was closed from cranial to caudal with loop prolene with continuous suture.

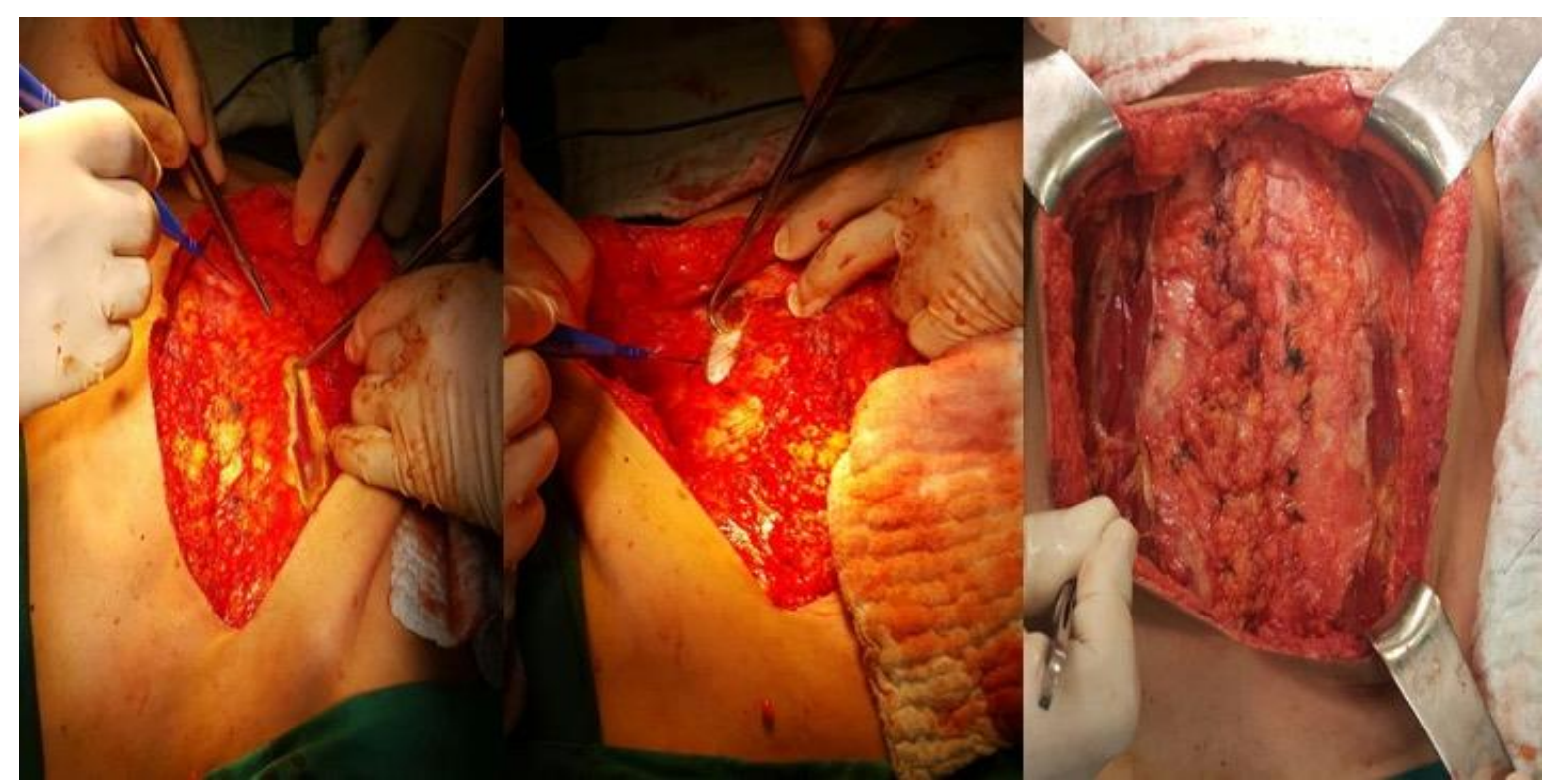

Figure 7: After the incisional hernia defect is closed, the aponeuroses of the obliquus externus and internus abdominis muscle are separated from the lateral edge of the rectus sheath until the transverse abdominis muscle is visible.

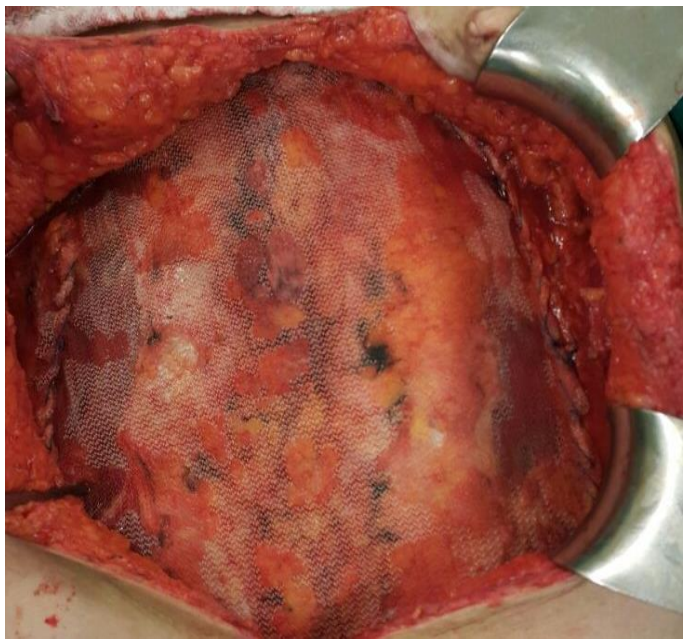

Figure 8: $30 * 30 \mathrm{~cm}$ sized polypropylene mesh is fixed to the externus and internus aponeurosis line that is released laterally, and $5 \mathrm{~cm}$ from the incision line in the cranial and caudal by continuous suture. 


\section{Postoperative follow-up}

All patients were monitored in the intensive care after the surgery. Early mobilization and clexane 4000 anti-Xa / $0.4 \mathrm{ml}$ treatment at the postoperative sixth hour were started for deep venous embolism prophylaxis. Clexane treatment were continued until the seventh day and then, aspirin was used. Nasogastric drainage was removed on the first postoperative day, and oral water was started and the patient was taken to the patient ward. The drainage was pulled out when the drainage outputs dropped below $50 \mathrm{cc}$ a day. All patients whose oral feeding was increased in line with their tolerance were exterminated when no surgical morbidity was observed. All patients were recommended to use abdominal corset within the first three months.

The diagnosis of sepsis was made in line with the increasing fever, clinical picture and acute phase reactant. The presence of erythema, necrosis, high fever and flix in the incision was regarded as surgical site infection. Oral intake was closed in patients who did not have intestinal drainage and vomited on the postoperative third day, and nasogastric drainage and parenteral feeding was started. The patients were evaluated for recurrence via examinations and phone calls one year after the surgery.

\section{RESULTS}

In the first phase of the study, incisional hernia was diagnosed in 21 patients, 5 patients were excluded form study due to additional surgery such as hepatectomy, cholecystectomy. This study included 16 patients who underwent surgery due to the diagnosis of incisional hernia between November 2016 and December 2017. Of 16 patients, nine $(56.25 \%)$ were male and seven $(43.75 \%)$ were female. The general mean age of the patients was 51.25 years while the mean age of male patients was 49 years and female patients was 54.1 years. Six $(37.5 \%)$ patients did not have any comorbid diseases. The mean body mass index was 25.3. Of the patients, $11(68 \%)$ had a habit of smoking. The information on the etiology of incisional hernia is presented in the table (Table 1).

\begin{tabular}{|c|c|c|}
\hline \multicolumn{2}{|r|}{ Parameters } & Number, \% \\
\hline \multirow[b]{2}{*}{ Gender } & Male & $9(\% 56,25)$ \\
\hline & Female & $7(\% 43,75)$ \\
\hline Age & \multicolumn{2}{|c|}{ Mean 51,25 (Min:24, Max: 73) } \\
\hline \multirow{5}{*}{ Co-morbidity } & None & $10(\% 62,5)$ \\
\hline & Diabetes & $2(\% 12,5)$ \\
\hline & COPD & $1(\% 6,25)$ \\
\hline & Diabetes + Hypertension & $2(\% 12,5)$ \\
\hline & Hypertension & $1(\% 6,25)$ \\
\hline \multirow[t]{2}{*}{ Smoking } & Non-user & $5(\% 31,25)$ \\
\hline & User & $11(\% 68,75)$ \\
\hline Body Mass Index & \multicolumn{2}{|c|}{ Mean $25,3 \mathrm{~kg} / \mathrm{m}^{2}\left(\right.$ Min: $17 \mathrm{~kg} / \mathrm{m}^{2}$, Max: $\left.33 \mathrm{~kg} / \mathrm{m}^{2}\right)$} \\
\hline \multirow{8}{*}{ Previous surgery } & Abdominal aortic aneurysm repair & $2(\% 12,5)$ \\
\hline & Whipple & $2(\% 12,5)$ \\
\hline & Cholecystectomy & $3(\% 18,75)$ \\
\hline & Colectomy (colon ca) & $2(\% 12,5)$ \\
\hline & Duodenal ulcer perforation & $3(\% 18,75)$ \\
\hline & Gastric ulcer perforation & $1(\% 6,25)$ \\
\hline & Sterchoral fistula secondary to trauma & $2(\% 12,5)$ \\
\hline & Perforated appendectomy & $1(\% 6,25)$ \\
\hline Hernia diameter & \multicolumn{2}{|c|}{ Mean: $11,26 \mathrm{~cm}$ (Min: $10 \mathrm{~cm}$ Max: $14 \mathrm{~cm})$} \\
\hline Hemorrhage & \multicolumn{2}{|c|}{ Mean: 100cc (Min: $10 \mathrm{cc}$ Max: $200 \mathrm{cc}$ ) } \\
\hline Operation time & \multicolumn{2}{|c|}{ Mean: 48 min, (Min: 35 min Max: 65 min.) } \\
\hline Drain withdrawal & \multicolumn{2}{|c|}{ Mean: 6.5 day (Min: 4 day Max: 12 day) } \\
\hline \multirow[t]{2}{*}{ Complication } & Skin necrosis & $1(\% 6,25)$ \\
\hline & Paralytic ileus & $2(\% 12,5)$ \\
\hline
\end{tabular}


The first incision was median superior and inferior in all patients. The hernia size measured in the computed tomography was $11.01 \mathrm{~cm}$ on average in men and $11.56 \mathrm{~cm}$ on average in women. The intravesical pressure measured intraoperatively before the surgery was $3.4 \mathrm{mmHg}$ on average. While the mean intravesical pressure was found as 12.25 $\mathrm{mmHg}$ after the abdomen was closed, the mean intravesical pressure was measured as $6.43 \mathrm{mmHg}$ after the relaxation incision and graft installment (Table 2). Intraoperative hemorrhage was $100 \mathrm{cc}$ on average and the duration of the surgery was 48 minutes on average. In the postoperative period, paralytic ileus responsive to treatment was observed in two patients and skin necrosis was observed in one patient. Nasogastric decompression was kept until the postoperative fifth day in patients on whom paralytic ileus was detected. Skin necrosis was treated with secondary recovery after the debridement. The pullout duration of drainages was 6.5 days on average (min: 4 days and max: 12 days). No pulmonary embolism, respiratory problems and compartment syndrome that may cause mortality developed in patients. Of 16 patients, 12 were checked with physical examination and superficial ultrasonography in the first year after the surgery. Four patients were reached via phone call. None of the 12 patients had recurrence and pain complaints. Four patients who were called also did not have any verbal complaint.

\begin{tabular}{|c|c|c|c|}
\hline $\begin{array}{l}\text { Pressure } \\
(\mathrm{mmHg})\end{array}$ & $\begin{array}{c}\text { Pre- } \\
\text { operative }\end{array}$ & $\begin{array}{c}\text { Intra- } \\
\text { operative }\end{array}$ & $\begin{array}{c}\text { Post- } \\
\text { operative }\end{array}$ \\
\hline Case 1 & 0 & 13 & 5 \\
\hline Case 2 & 2 & 8 & 6 \\
\hline Case 3 & 5 & 14 & 6 \\
\hline Case 4 & 5 & 13 & 4 \\
\hline Case 5 & 6 & 9 & 7 \\
\hline Case 6 & 1 & 8 & 6 \\
\hline Case 7 & 1 & 10 & 5 \\
\hline Case 8 & 1 & 7 & 4 \\
\hline Case 9 & 7 & 11 & 7 \\
\hline Case 10 & 5 & 15 & 7 \\
\hline Case 11 & 2 & 9 & 6 \\
\hline Case 12 & 5 & 20 & 9 \\
\hline Case 13 & 3 & 22 & 9 \\
\hline Case 14 & 3 & 10 & 6 \\
\hline Case 15 & 2 & 17 & 8 \\
\hline Case 16 & 7 & 10 & 8 \\
\hline
\end{tabular}

\section{DISCUSSION}

There are different ratios in the literature regarding the incidence of incisional hernia, which are iatrogenic incision site hernia. Despite different percentages, the incisional hernia ratios were reported as $13 \%$ after primary closing of the incision line, and $25 \%$ in patients who developed postoperative surgical complications and wound site infection (4). This ratio increases to $63 \%$ in patients who have a history of previous abdominal and incisional hernia surgery $(4,5,7)$. The etiology of incisional hernia is multifactorial. The most common factors are obesity, smoking, incision type, surgical material used and surgical site infection (6). Half of the incisional hernia cases are obese. Respiratory and cardiac dysfunction secondary to obesity causes a decrease in the wound site oxygenation. The formation of incisional hernia is almost inevitable in the clinical table of surgical site infection secondary to obesity (7). Incision type also plays a role in the development of hernia. Compared to transverse incisions, incisional hernia developed 3-5 times more in vertical incisions. Tables that increase the intraabdominal pressure due to the incision of facial aponeurotic fibers in vertical incisions and muscle contractions cause decomposition and incisional hernia in the wound site. Additionally, the materials of suture performed closer than $2 \mathrm{~cm}$ to the wound edge may cause the formation of hernia by cutting the wound site (8-10). While male sex was dominant in this study, female patients included in the study were advanced ages. The first surgery incision was median superior and inferior in all patients and the patients had a habit of smoking.

The treatment of incisional hernias, for which the only treatment option if surgery, is quite difficult. If not treated, it may cause mortality due to intestinal incarceration, obstruction, strangulation and perforation. Additionally, it is accompanied by socio-economic loss and cosmetic dysfunction (11). All patients were operated under elective conditions in this study. The surgical treatment of incisional hernia has two stages. The first one is the closing of facial defect and the second is the placement of mesh in the surgical site. Prior to the common use of prosthetic mesh, various techniques have been described to close facial defects. Despite all techniques, there is still a serious problem regarding the closing of large and giant hernia defects. Ramirez described the component separation technique, a fascia-fascia closing technique, that allows the tension-free closing of very large and giant fascia defects that cannot be closed primarily or have a high probability of postoperative complication development in mesh application for the first time in 1990 (12). The fact that fascia defects up to subxiphoid $6 \mathrm{~cm}$, midline $10 \mathrm{~cm}$, and suprapubic 5 $\mathrm{cm}$ can safely be repaired with this technique has become widespread (13). The partition technique 
was described for larger fascia defects. This technique, which is not as popular as the component separation technique, aims to obtain more muscle elasticity with parallel, parasagittal and gradual release of the external oblique and transverse abdominis muscle (14). The application of the partition technique is easier and the application duration is shorter. It was published in the study by Lindsey that midline defects up to $20 \mathrm{~cm}$ are closed without any problem with the partition technique. The recurrence rates can be minimized by adding mesh to the partition technique (14). Another important factor in the incisional hernia surgery is the placement of the prosthetic mesh on the abdominal wall. The most preferred placement of mesh among surgeons is onlay placement described by Ramirez or sublay placement by Rives - Stoppa $(12,15)$. Langer et al. determined that the onlay or sublay placement of mesh did not make a difference in terms of recurrence and that the frequency of local complications was higher among the onlay patient group (16). Local complications were due to large dissection site, epigastric, perforating artery injuries and seroma. Memon et al. found that the perioperative complication ratio was $23 \%$ among 60 patients with onlay mesh repair (17). While the percentage of surgical site infection was $20 \%$, it was reported that the recurrence ratio was $7 \%$ in 20 month follow-up. Duce et al. reported that the recurrence ratio after mesh placement was $1.5 \%$ and the postoperative complication ratio was $27 \%$ (18). Considering the ratios of recurrence and postoperative complications in the treatment of incisional hernias, the most appropriate surgical treatment option looks like sublay mesh application. Some of the distinct disadvantages of the sublay technique are long operation duration, difficulty of intraoperative dissection, the frequency of iatrogenic intestinal injuries and long learning duration (19). Compared to the sublay technique, onlay technique has higher recurrence rates and more local complications. On the other hand, the advantages of the technique are easy applicability, short operation duration and relatively lower general complication rates compared to sublay. The recurrences after the incisional hernia surgery usually occur on the edge of the mesh. The reason of this is insufficient surface of the mesh in contact with the fascia. Mesh must close all fascia defects and extend at least $4-5 \mathrm{~cm}$ to from the primary defect to all sides (20).

The size of the hernia was above $10 \mathrm{~cm}$ and the hernia was in the complex incisional hernia group in all patients who were operated under elective conditions. In the technique described in this study, the hernia sac is dissected from the adjacent muscle plans without opening the sac compared to other conventional incisional hernia techniques. Thus, the intraabdominal area is not entered, the operation duration is shortened and possible intestinal injuries are avoided. The operation duration and bleeding amount are quite lower than other techniques. We encountered severe intraabdominal pressure which can be the source of embolisms that may cause postoperative cardiac, respiratory dysfunction and mortality due to the primary closing of the facial defect in complex hernias. Muscle relaxation obtained with the transection of externus and internus oblique muscles up to the transverse muscle caused a serious regression in the intraabdominal pressure. Compared to the commonly used component separation and partition techniques, this techniques is applied more easily, has a short learning and surgical duration and ensures similar effective muscle relaxation. The probability of recurrence was minimized with the tension-free fixation of the large mesh prepared to the transection plans. Local complications that were commonly described in onlay mesh applications in the postoperative period were not observed in this study. Only one patient had a local wound site complication in this study. Two patients had regressive ileus with medical treatment. According to the Swedish Hernia Registry Report, $31 \%$ of the patients described pain in the incision site at the end of 2-3 years following the incisional hernia surgery (21). Postoperative continuous pain is due to iatrogenic nerve injuries, tense placement of the mesh on the abdominal wall, materials used for the fixation of the mesh and inflammatory reaction due to the mesh. No recurrence was observed in the patients included in this study and none of them had postoperative pain complaint. This study has many limitations. Firstly, the sample was quite limited and small. The actual results of this technique can be provided with comparative prospective randomized studies conducted with other incisional hernia closing methods.

In conclusion, the golden standard surgical method for the incisional hernia surgery has yet to be determined. The appropriate surgical treatment option can be determined and guiding in large case series supported with prospective randomized studies. Despite the limitations of this study, this technique should be kept in mind as an alternative treatment option for incisional hernia surgery with its easy applicability and low complication rates.

\section{Conflict of interest}

No conflict of interest was declared by the author.

\section{REFERENCES}

1. Schoetz DJ, Coller JA, Veidenheimer MC: Closure of abdominal wounds with polydioxanone: A prospective study. Arch Surg 1988:123:72-74.

2. Wantz GE. Incisional hernioplasty with Mersilene. Surg Gynecol Obstet. 1991;172(2):129-137. 
3. Sukkar SM, Dumanian GA, Szczerba SM et al. Challenging abdominal wall defects. Am J Surg 2001:181:115-121

4. Burger JA, Luijendijk R, Hop WC et al. Longterm follow-up of randomized controlled trial of suture versus mesh repair of incisional hernia. Annals of Surgery 2004: 240(4): 578-585.

5. Klinge U, Conze J, Krones CJ, Schumpelick V. Incisional hernia: open techniques. World J. Surg. 2005; 29:1066-1072.

6. Vidovic D, Jurisic D, Franjic BD, et al. recurrence after incisional hernia repair. Hernia 2006:10:322-325.

7. Gangură AG, Palade RŞ. Tactical and surgical techniques issues in the surgical treatment of incisional hernias. Journal of Medicine and Life 2014;7(3);428-432.

8. Rizk NN. A new description of the anterior abdominal wall in man and mammals. J Anat 1980:131:373-385.

9. Askar OM. Aponeurosis hernias: recent observation upon paraumbilical and epigastric hernias. Surg Clin North Am 1984:64:315.

10. Klippel $\mathrm{CH}$ Jr. The embryo considered as a vector field. In: El Shafic M, Klippel CH Jr (eds). Associated Congenital Anomalies. Williams \& Wilkins, Baltimore, 1981, pp:157-163.

11. Strâmbu V, Radu P, Brãtucu $M$ et al. Rives Technique, A Gold Standard for Incisional Hernias - Our Experience. Chirurgia 2013:108:46-50

20. Eker HH, Hansson BM, Buunen M, et al. Laparoscopic vs. open incisional hernia repair: a randomized clinical trial, JAMA Surg. 2013:148(3): 259-263.
12. Ramirez OM, Ruas E, Dellon AL. ' Components separation" method for closure of abdominalwall defects: an anatomic and clinical study. Plast Reconstr Surg 1990:86:519-526.

13. Shih PK. Difficult abdominal wall closure: component separation versus partition technique. Hernia 2014:19(2): 301-305.

14. Lindsey JT. Abdominal wall partitioning (the accordion effect) for reconstruction of major defects: a retrospective review of 10 patients. Plast Reconstr Surg 2003:112:477-485

15. Stoppa RE: The treatment of complicated groin and incisional hernias. World J Surg 1989:13:545-554.

16. Langer C, Liersch T, Kley C et al. Twenty-five years of experience in incisional hernia surgery. A comparative retrospective study of 432 incisional hernia repairs. Chirurg 2003:74(7):638-645.

17. Memon AA, Khan H, Zafar G et al. Repair of large and giant incisional hernia with onlay mesh: perspective of a tertiary care hospital of a developing country, Int. J. Surg. 2013:11(1):4145.

18. Duce AM, Noguerales F, Villeta $R$ et al. Modifications to Rives technique for midline incisional hernia repair. Hernia 2001:5:70-72.

19. Carlson MA, Ludwig KA Condon RE. Condon, Ventral hernia and other complica- tions of 1,000 midline incisions, South. Med. J. 1995;88 (4):450-453.

21. Franneby U, Sandblom G, Nordin P, et al. Risk factors for long-term pain after hernia surgery, Ann. Surg. 2006:244(2);212-219. 